\title{
In vitro anthelmintic activity of Pothomorphe umbellata (L.) Miq. (Piperaceae) against gastrointestinal parasites from sheep
}

\author{
Luis Eduardo Ferreira*, Pedro Castro, Franca Suzelei, Beleboni Rene \\ From 5th Congress of the Brazilian Biotechnology Society (SBBIOTEC) \\ Florianópolis, Brazil. 10-14 November 2013
}

Sheep farming in Brazil has been proved to be a promising economical activity by the offering of products with increased interest. Infections with gastrointestinal parasites from family of Trichostrongylidae, especially represented by Haemonchus contortus, are one the most limiting problem in sheep production, aggravated by the increasing resistance of nematodes to traditional anthelmintic drugs. Ethnopharmacological data have indicated the Pothomorphe umbellata as a promising alternative for the control of gastrointestinal nematodes. The aim of this work was to evaluate the in vitro anthelmintic effects of $P$. umbellata aqueous leaf extract against eggs, infective larvae and adult forms of parasitic nematodes from Trichostrongylidae family from sheep. At higher doses, P. umbellata extract showed $95.82 \%$, and $32.18 \%$ of efficacy in egg hatch test (EHT) and larval motility test (LMT), respectively. In the adult worm motility test, worms were completely immobilized within the first 4-6 hours of nematode exposition to different dilutions of extract. Thus, these data showed that the evaluated extract presented significant anthelmintic activity, which are of high biotechnological interest and useful towards the growth of sheep farming in Brazil.

Published: 1 October 2014

\section{References \\ 1. Botura MB, Santos JDG, Silva GD, Lima HG, Oliveira JVA, Almedia MAO, Batatinha MJM, Branco A: In vitro ovicidalandlarvicidalactivityof Agave sisalanaPerr. (sisal) on gastrointestinal nematodes of goats. Veterinary Parasitology 2013, 192(1-3):211-217. \\ 2. Ferreira LE, Castro PM, Chagas AC, França SC, Beleboni RO: In vitro anthelmintic activity of aqueous leaf extract of Annona muricata $L$.}

Unit of Biotechnology, Ribeirão Preto University (UNAERP), Ribeirão Preto, SP, Brazil Attribution License (http://creativecommons.org/licenses/by/4.0), which permits unrestricted use, distribution, and reproduction in any medium, provided the original work is properly cited. The Creative Commons Public Domain Dedication waiver (http://creativecommons.org/publicdomain/zero/1.0/) applies to the data made available in this article, unless otherwise stated.
(Annonaceae) against Haemonchus contortus from sheep. Experimental Parasitology 2013, 134(3):327-332.

3. Krychak-Furtado S, Silva AL, Miguel OG, Dias Jde F, Miguel MD, Costa SS, Negrelle RR: Effectiveness of Asteraceae extracts on Trichostrongylidae eggs development in sheep. Rev Bras Parsitol Vet 2011, 20(3):215-218.

4. Hounzangbe-Adote MS, Paolini V, Fouraste I, Moutairou K, Hoste H: In vitro effects of four tropical plants on three life-cycle stages of the parasitic nematode, Haemonchus contortus. Research in Veterinary Science 2005 , 78(2):155-160.

5. Kozan E, Anul SA, Tatli II: In vitro anthelmintic effect of Vicia pannonica var.purpurascens on trichostrongylosis in sheep. Experimental Parasitology 2013, 134(3):299-303.

doi:10.1186/1753-6561-8-S4-P155

Cite this article as: Ferreira et al.: In vitro anthelmintic activity of

Pothomorphe umbellata (L.) Miq. (Piperaceae) against gastrointestinal parasites from sheep. BMC Proceedings 2014 8(Suppl 4):P155.

Submit your next manuscript to BioMed Central and take full advantage of:

- Convenient online submission

- Thorough peer review

- No space constraints or color figure charges

- Immediate publication on acceptance

- Inclusion in PubMed, CAS, Scopus and Google Scholar

- Research which is freely available for redistribution

Submit your manuscript at
www.biomedcentral.com/submit

C Biomed Central \\ () Biomed Central}

